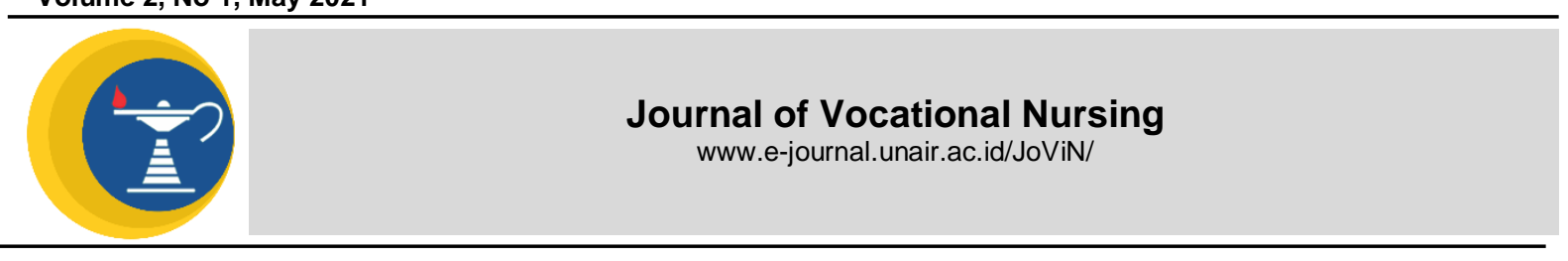

\title{
NURSING CARE IN EFFECTIVENESS OF BREATHING FOR CHRONIC OBSTRUCTION PATIENTS IN RSI NASHRUL UMMAH LAMONGAN
}

\author{
Annisa Dwi Anugrah
}

Research Report

RS Denisa Gresik

\section{A B S TRACT}

Introduction: Air pollution can cause respiratory system disorders in the form of alveoli damage, airway, and lung tissue inflammation. Inflammation of the lungs can damage the respiratory tissue and stimulate excess sputum production which causes ineffective airway clearance. This process, if it takes a long time, causes irreversible structural damage to the airway wall. This condition can progress to severe airway obstruction, called COPD. This research aims to explain nursing care for patients with Chronic Obstructive Pulmonary Disease (COPD) in the Tuberose Room at RSI Nashrul Ummah Lamongan. Methods: The research design used in this research is case study research. Participants in the study for Mr. "K" 69 years. The result of problem identification that arises is Chronic Obstructive Pulmonary Disease (COPD) with the main nursing diagnosis of Ineffective Airway Cleansing. Interventions that were emphasized and carried out in the field in cases were maintaining oxygen therapy, semi-fowler position, and administration of a nebulizer. The final evaluation of nursing diagnoses in patients was not resolved within the specified time. Result: Implementation of Nursing Care Ineffective Airway Cleansing of COPD patients in the Tuberose Room at RSI Nashrul Ummah Lamongan, there are still gaps with the literature. Conclusion: Suggestions for nurses are expected to be the focus of nurses in developing science to be applied to all nursing personnel in providing nursing care to ineffective airway cleaning for COPD patients.

\author{
ARTICLE INFO \\ Received May 18, 2021 \\ Accepted May 30, 2021 \\ Online May 31, 2021 \\ ${ }^{*}$ Correspondence: \\ Annisa Dwi Anugrah \\ *Email: \\ annisadwianugrahwati@gmail.com
}

\section{Keywords:}

COPD, Ineffective Airway Cleansing, Nursing Care

\section{INTRODUCTION}

Air pollution can cause respiratory system disorders in the form of damage to the alveoli, airways, and inflammation of the lung tissue. Inflammation of the lungs can damage respiratory tissues and stimulate excess phlegm production, which can lead to ineffective airway clearance. This process, if it is prolonged and continuous, can cause permanent structural damage to the airway walls. This damage will cause injury and make the peripheral channels narrow and blockage. This condition can progress to severe airway obstruction, called Chronic Obstructive Pulmonary Disease (Ghofar, 2014). Categorized COPD into the top four noncommunicable diseases that have a high mortality rate after cardiovascular disease, stroke, and HIV / AIDS. The Global Burden of Disease Study reported the prevalence of COPD cases globally in 2016 of 251 million patients. Deaths due to COPD occur in many countries with low and middle-low economies, amounting to more than 90\% (WHO, 2017). The prevalence of COPD diagnosted in Indonesia in 2013 was 3.7 (Riskesdas, 2013). The East Java Healt Office survey in 2011 on COPD patients at 17 health centers, found a morbidity rate of $13.5 \%$ pulmonary emphysema $13.1 \%$, chronic bronchitis $7.7 \%$, and asthma $7.7 \%$.

Conditions that can cause COPD to include impaired fetal lung development during the womb and in childhood, for example, underweight at birth and respiratory tract infections (Global Initiative for Chronic Obstructive Lung Disease. These causative factors can irritate the airway resulting in hypersecretion of mucus. The work of the cilia and the function of macrophage cells is disrupted, causing damage to the alveoli, airway, and inflammation of the lung tissue. If this situation lasts for a long time and 
continues, it can cause respiratory failure, cor pulmonary, pneumothorax, disability and death (Ghofar, 2014).

The main role of the nurse in COPD cases is to increase the patient's knowledge about how to prevent a recurrence. Prevention of recurrence is carried out by pharmacological and non-pharmacological treatments. Pharmacological treatment is the administration of anti-inflammatory, bronchodilators, antihistamine, steroid, and oxygen. Non-pharmacological treatments include performing lung hygiene; physical exercise, such as walking to improve fitness and train the skeletal muscles to be more effective; avoiding irritants, such as cigarette smoke; prevents allergens from entering the body; and diet, by eating small portions but often (Muttaqin, 2014).

\section{MATERIALS AND METHODS}

The research design used in this research is case study research. Participants in this study was Mr. "K" 69 years old with a diagnosis of COPD in the Tuberose Room at RSI Nashrul Ummah Lamongan. Data collection techniques by interview, observation, and documentation. Test the validity of the data through additional sources of information using triangulation of three data sources including patients, patient's families and health workers. Data analysis was carried out by collecting data, reducing data, presenting data, and conclusions.

\section{RESULTS AND DISCUSSION Assessment}

In the case review, it was found that Mr. "K" is a 69 years old male with a COPD case. The identity of COPD patients can affect both men and women aged $>40$ years, but men are more at risk of suffering from COPD than women (Muttaqin, 2014). This is due to the large number of men who have a smoking habit, both active and passive smokers, are very at risk of developing COPD (Salawati, 2016). In the case review, there was a cough complaint. This is because coughing occurs due to the presence of bacteria, fungi, viruses, or cigarette smoke which causes inflammation of the lungs and can damage the respiratory tissue and stimulate the production of excess sputum which makes the airway narrow and clogged, so that the movement of air from and out of the lungs is disturbed. which causes a decrease in effective cough (Muttaqin, 2014).

In the case review, it was found that the patient had a history of smoking \pm 30 years ago. This is in accordance with the literature review according which states that a history of previous illnesses obtained a history of upper respiratory tract infections, sore throat, tonsils, sinusitis, nasal polyps, and the presence of allergens that are suspected to trigger disease attacks, such as cigarette smoke, pollution, air and dust (Muttaqin, 2014). This is because the irritating substances and toxic substances contained in a cigarette such as nicotine, carbon monoxide and tar are agents that trigger the attack of COPD (Salawati, 2016).

In the case review, it was found that the patient's family said that no one in the family had a history of COPD, asthma, and shortness of breath. This is not in accordance with the literature review (Muttaqin, 2014), which states that family history in patients with COPD usually results in a family history of suffering from COPD, asthma, or shortness of breath. In fact, the COPD disease suffered by patients is not due to a genetic relationship passed down from parents or family but rather towards unhealthy living habits (K. N. Berawi \& Theodorus, 2017). The psycho, socio, and spiritual history of COPD patients is a psychological assessment of the patient covering several dimensions that allow nurses to obtain clear perceptions of the patient's emotional, cognitive, and behavioral status (Muttaqin, 2014). Families are people who are always close to patients, so nurses must involve the family's role in carrying out the care for COPD patients (Dasuki, 2018).

In the case review, it was found that the patient's appetite decreased during hospitalization. The nutritional patterns of COPD patients often occur nausea and lack of nutritional fulfillment (Muttaqin, 2014). This is due to the psychological response of patients who experience depression and increased energy needs as a result of increased respiratory muscles due to chronic hypoxemia and hypercapnia resulting in hypermetabolism (A. F Radhitya \& Zairus, 2014).

In the study of the elimination pattern, there is a gap between the case review and the literature review. In the case review, it was found that the patient urinated smoothly and defecated 2 times / day, with no pain when urinating or defecating. Elimination pattern of patients with COPD is likely to develop constipation, and measurement of urine output needs to be done because it relates to fluid intake. This occurs because of the side effects of giving Phosphodiesterase-4 inhibitor drugs (A. Y Soeroto \& Suryadinata, 2014).

In the case review, it was found that while in the hospital the patient slept more often, the patient complained that his body and legs were weak so that when doing activities to 
defecate or urinate, the family assisted him. Patients with COPD generally experience weakness, malaise, shortness of breath and physical fatigue when doing activities (Muttaqin, 2014). This is due to a lack of $O 2$ supply and insufficient psychological or physiological energy to continue or complete daily life activities that should or want to be done so that patients need help from others in carrying out daily activities (Wilson, 2014).

In the case review, it was found that while in the hospital, patients often took 3 hours nap every day and often woke up at night due to tightness and coughing. Patients with COPD generally experience sleep rest disturbances (Muttaqin, 2014). The active sympathetic nerves make the patient unable to relax so that they are unable to cause drowsiness and emotional stress. Anxiety can increase norepinephrine levels through stimulation of the sympathetic nervous system resulting in less NREM stage 4 sleep time and many REM stages that change and make people wake up (Yatun, R.U, Widayati, N., \& Purwandari, 2016).

In the case review, it was found that while in the personal hygine hospital the patient was assisted by the family. The personal hygiene patterns of COPD patients do not experience deficits in self-care, but patients are assisted by their families (Muttaqin, 2014) . In the case review, the results of inspection were obtained: barrel chest shape, no lumps, no skin injuries or abnormalities, clean skin, there are respiratory muscles; palpation: decreased right and left vocal fremitus, no lumps, no tenderness; percussion: hypersonic pulmonary sound, heart deafening sound; auscultation: there are ronchi breath sounds in both lung fields, single S1 S2 heart sound. The results of the examination are in accordance, namely inspection: in patients with COPD, it is seen that there is an increase in breathing effort and frequency, as well as the use of breathing muscles (sternocleidomastoid) (Muttaqin, 2014). On inspection, it is usually seen that the patient has a barrel chest shape, thinning of muscle mass, breathing with lips closed, and abnormal ineffective breathing; palpation: on palpation the expansion increases and tactile fremitus usually decreases; percussion: on percussion, usually there is a normal sound to hypersonic, while the diaphragm flattens down; auscultation: frequent ronchi breath sounds and wheezing according to the severity of bronchial obstruction, heart sounds S1-S2 lupdup are heard louder. This occurs because the pursed lip breathing stage can prolong exhalation, and will reduce air loss space trapped in the airway, as well as increase $\mathrm{CO} 2$ output and reduce $\mathrm{CO} 2$ levels in arterial blood and increase $\mathrm{O} 2$ so that homeostasis will be improved, namely $\mathrm{CO} 2$ levels in the airway. arterial blood is normal, blood $\mathrm{PH}$ will also be normal (Muttaqin, 2014).

There is a gap between the case review and the literature review. In the case review, laboratory and sputum examinations were performed. Explained that supporting examinations in COPD patients are carried out several examinations including lung function, blood gas analysis, laboratory tests, sputum examination, chest radiological examinations (AP and Lateral), bronchogram examination, ECG, and echocardiography (Muttaqin, 2014) . This is to establish the diagnosis of COPD and determine the prognosis and treatment, namely by assessing symptoms, assessing spirometry, assessing the risk of exertion, and assessing comorbidity (C. Vogelmeier, Criner, G., Martinez, F., Anzueto, A., Barnes, P., Bourbeau, J. \& . Frith, 2017).

In giving therapy, there was no gap between case reviews and literature reviews. In the case review, it was found that the therapy given was oxygen, bronchodilators, antibiotics, mucolytic agents. This is in accordance with the literature review according to Muttaqin (2014) Bronchodilators, alpha-1 Augmentation therapy, antibiotics, mucolytics (mucokinetics, mucoregulators) and antioxidants. This is because bronchodilator drugs are useful for increasing FEV or changing spirometric variables by affecting smooth muscle tone in the airway, alpha-1 Augmentation therapy. This therapy is aimed at young patients with severe hereditary alpha1 antitrypsin deficiency, antibiotics are used to treat bacterial infections that trigger exacerbations, and mucolytics (mucokinetics, mucoregulators) and antioxidants are used to thin thick mucus (sputum) so that it is easy to remove (Muttaqin, 2014).

\section{Nursing diagnoses}

According to Muttaqin, (2014) there are 6 nursing diagnoses in patients with COPD that may appear according to the patient's complaints, including 1) ineffective airway cleaning is related to bronchocontriction, accumulation of airway secretions, and decreased effective coughing 2) Impaired fulfillment of nutritional needs less than needed body associated with decreased appetite 3) ADL disorders associated with general physical weakness and fatigue. 


\section{Nursing Implementation}

In the case review, it was found in the patient, teaching the patient how to cough effectively, adjust the position of the semi-fowler patient, help the patient practice deep breathing, assess the color, thickness, and amount of sputum, maintain fluid intake at least 2500 $\mathrm{ml} /$ day, observe TTV, perform chest physiotherapy with postural drainage techniques, chest splinting and fibration, and collaboration in administering pharmacological therapy. This is in accordance with the literature review according to Muttaqin, (2014) which states that the nursing plan is to assess the color, thickness, and amount of sputum, adjust the semi-fowler position, teach effective coughing, help patients practice deep breathing, maintain fluid intake at least 2500 $\mathrm{ml} /$ days, perform chest physiotherapy with postural drainage techniques, chest splinting and fibration, collaborative drug administration (bronchodilators, mucolytic agents and expectorants, and corticosteroids). The interventions that have been given are adjusted to the facilities owned by the hospital (Muttaqin, 2014).

\section{Nursing Evaluation}

In the case review the authors carry out nursing actions to teach patients how to cough effectively, adjust the position of the semifowler patient, help patients practice deep breathing, assess the color, thickness and amount of sputum, maintain a liquid intake of at least $2500 \mathrm{ml} /$ day, observe TTV, and collaborate in administering pharmacological therapy. In a case review of nursing actions carried out according to Muttaqin, (2014), namely teaching patients how to cough effectively, adjusting the position of semifowler patients, helping patients to practice deep breathing, assessing the color, thickness and amount of sputum, maintaining liquid intake at least $2500 \mathrm{ml} /$ day, observing TTV, performs chest physiotherapy with postural drainage techniques, chest splinting and fibration, and collaborates in providing pharmacological therapy. This chest physiotherapy is not done because the patient can cough up phlegm after being given a nebulizer every 8 hours.

\section{CONCLUSION}

The author implements nursing care in accordance with the plans that have been made on the intervention, namely the medical diagnosis of COPD. At the evaluation stage, it was found that not all objectives could be achieved in accordance with the predetermined target time. The success of the actions that have been taken can be seen from the changes and improvements in the patient's health condition in accordance with the objectives of the outcome criteria as previously made.

\section{REFERENCE}

A. F Radhitya \& Zairus, D. (2014). Chronic Obstructive Pulmonary Disease Exacerbation. J Agromed Unila.

A. Y Soeroto \& Suryadinata, H. (2014). Penyakit Paru Obstruktif Kronik. Ina $J$ Chest Crit And Emerg Med.

C. Vogelmeier, Criner, G., Martinez, F., Anzueto, A., Barnes, P., Bourbeau, J., .., \& . Frith, P. (2017). Global Strategy For The Diagnosis, Management, And Prevention Of Chronic Obstructive Lung Disease 2017. American Journal Of Respiratory And Critical Care Medicine, 195(5), 557-582.

Dasuki. (2018). Pengaruh Dukungan Keluarga Terhadap Efikasi Diri Pasien Ppok Di Poliklinik Paru Rsud Koja Jakarta Utara. Jurnal Mutiara Ners, 1(1), 22.

Ghofar, A. (2014). Hubungan Perilaku Merokok Dengan Kejadian Ppok Di Paviliun. 4(1). Retrieved from Jurnal Eduhealth

K. N. Berawi \& Theodorus, E. (2017). Defisiensi Alpha 1-Antitrypsin Sebagai Faktor Risiko Penyakit Paru Obstruktif Kronis. Majority, 6(2), 28-29.

Muttaqin, A. (2014). Asuhan Keperawatan Klien Dengan Gangguan Sistem Pernapasan. Jakarta: Salemba Medika.

Organization, W. H. (2017). Chronic Obstructive Pulmonary Disease.

R. U Yatun, Widayati, N., \& Purwandari, R. (2016). Hubungan Nilai Aliran Puncak Ekspirasi (Ape) Dengan Kualitas Tidur Pada Pasien Ppok Di Poli Spesialis Paru B Rumah Sakit Paru Jember. E-Jurnal Pustaka Kesehatan, 4(1), 91.

Riskesdas. (2013). Badan Penelitian dan Pengembangan Kesehatan Kementerian RI. Jakarta: Kementrian Kesehatan RI.

Salawati, L. (2016). Hubungan Merokok Dengan Derajat Penyakit Paru Obstruksi Kronik. Jurnal Kedokteran Syiah Kuala, 16(3), 165-166.

Wilson, A. C. P. \&. (2014). Patofisiologi Konsep Klinis Proses-Proses Penyakit. Jakarta: EGC. 